Note

\title{
Cleaning of Alumina Fouled with Bovine Serum Albumin by the Combined Use of Gaseous Ozone and Alkaline Electrolyzed Water
}

\author{
ATSUHIKO TAKEHARA, HIROMI URANO, AND SATOSHI FUKUZAKI* \\ Industrial Technology Center of Okayama Prefecture, 5301 Haga, Okayama 701-1296, Japan
}

Received 4 October 2000/Accepted 14 December 2000

\begin{abstract}
Alumina $\left(\mathrm{Al}_{2} \mathrm{O}_{3}\right)$ particles fouled with bovine serum albumin (BSA) were cleaned with alkaline electrolyzed water and $\mathrm{NaOH}$ solutions of different pHs. The efficiency and rate of BSA desorption during batchwise and continuous cleaning with alkaline electrolyzed water depended on the solution pH, i.e., the hydroxide ion concentration. Pretreatment of BSA-fouled $\mathrm{Al}_{2} \mathrm{O}_{3}$ with $0.3 \%$ ( $\mathrm{v} / \mathrm{v}$ ) gaseous ozone markedly facilitated $\mathrm{BSA}$ desorption during subsequent cleaning with alkaline electrolyzed water, depending on the length of pretreatment. The results suggest that the efficiency of cleaning with gaseous ozone and alkaline electrolyzed water (pH 11.7) in combination is comparable to that of cleaning with high-pH $\mathrm{NaOH}$ solutions (pH>13.0) alone.
\end{abstract}

Key words : Alkaline electrolyzed water/Ozone/Cleaning/Protein fouling.

The control of microorganisms in food products and on surfaces of food-handling equipment is essential to provide consumers with wholesome and safe products. Products are often biologically contaminated from equipment surfaces, and therefore food residues that serve as nutrients for microorganisms on foodcontact surfaces should be removed by cleaning after each processing operation. In the food and dairy industry, alkaline detergents and hypochlorites have so far been the most widely used chemicals in cleaning and sanitizing operations (Clegg, 1962; Mitchell, 1981; Twomey, 1968).

Recently, electrolyzed water has been receiving attention as a novel disinfectant and cleaning solution. When $\mathrm{NaCl}$ solution is electrolyzed through a membrane, acidic electrolyzed water ( $\mathrm{pH} 2$ to 3 ), containing hypochlorous acid ( $\mathrm{HOCl}$ ) which is generated from the reaction of $\mathrm{Cl}_{2}$ and $\mathrm{H}_{2} \mathrm{O}$, is generated at the anode site, while alkaline electrolyzed water $(\mathrm{pH} 11$ to 12 ) is generated at the cathode site. Acidic electrolyzed water has been demonstrated to have bactericidal activity against various types of bacteria

${ }^{*}$ Corresponding author. Tel : +81-86-286-9600, Fax : +8186-286-9630.
(Nakagawara et al., 1998; Ueda et al., 1999) and has been used for medical, agricultural, and industrial purposes. On the other hand, practical use of alkaline electrolyzed water is presently undefined and limited to preliminary cleaning before the disinfecting operation with acidic electrolyzed water. It is expected that for the purpose of cleaning, the alkalinity of alkaline electrolyzed water is not sufficient to solubilize organic fouling deposits on the equipment surface. However, the efficiency of cleaning with alkaline electrolyzed water is still not fully understood.

In our previous paper (Takehara et al., 2000), we reported that the efficiency of the alkali cleaning of alumina $\left(\mathrm{Al}_{2} \mathrm{O}_{3}\right)$ fouled with bovine serum albumin (BSA) increased with increasing $\mathrm{pH}$ of the $\mathrm{NaOH}$ solution over the $\mathrm{pH}$ range of 12.0 to 13.5. Furthermore, it was found that pretreatment of $\mathrm{BSA}$-fouled $\mathrm{Al}_{2} \mathrm{O}_{3}$ with gaseous ozone markedly accelerated the BSA removal during the subsequent alkali cleaning, even when a low-pH NaOH solution was used. This finding stimulated our interest in the application of alkaline electrolyzed water in combination with ozone pretreatment for cleaning operations.

The objectives of this study were to compare the ability of alkaline electrolyzed water and $\mathrm{NaOH}$ 
solutions of different $\mathrm{pHs}$ to remove protein from equipment surfaces, and to examine the effectiveness of the combined use of gaseous ozone and alkaline electrolyzed water for cleaning purposes in a laboratory model system. We used BSA as a model protein and $\mathrm{Al}_{2} \mathrm{O}_{3}$ particles as a model material having a hard surface, such as ceramic membrane and metallic materials, because all metal surfaces are covered with thin oxide layers under atmospheric conditions. Gaseous ozone at $0.3 \%(\mathrm{~V} / \mathrm{v})$ was used for the pretreatment of BSA-fouled $\mathrm{Al}_{2} \mathrm{O}_{3}$ particles.

$\alpha-\mathrm{Al}_{2} \mathrm{O}_{3}$ particles (Sumicorundum AA-5; lot YM6601) were supplied by Sumitomo Chemical Co. Ltd. (Tokyo); their specific surface area and mean diameter were $0.5 \mathrm{~m}^{2} / \mathrm{g}$ and $4.6 \mu \mathrm{m}$, respectively. BSA (fraction V; lot M7G9556) was obtained from Nacalai Tesque Inc. (Kyoto). All other chemicals were of analytical grade and were purchased from commercial sources. Alkaline electrolyzed water was generated at the cathode site by electrolysis of $0.1 \%$ $\mathrm{NaCl}$ solution through a membrane using an electrolyzed water generator (Super Oxseed Labo; Amano Corp, Yokohama). The $\mathrm{pH}$ of the alkaline electrolyzed water was controlled by electrolysis time over the $\mathrm{pH}$ range of 10.5 to 11.7 . Alkaline electrolyzed water and $\mathrm{NaOH}$ solutions of different pHs were freshly prepared before use. Ozone was generated from pure oxygen $(99.999 \%, \mathrm{v} / \mathrm{v})$ by a laboratory silent discharge ozonizer (Model 961; Ohnit Co. Ltd., Okayama) equipped with an ozone monitor (EG2001; Ebara Jitsugyo Co. Ltd., Tokyo).

The BSA-fouled $\mathrm{Al}_{2} \mathrm{O}_{3}$ particles were prepared at $40^{\circ} \mathrm{C}$ as described previously (Takehara et al., 2000). The amount of adsorbed BSA $(\Gamma)$ was $4.0 \pm 0.1 \mathrm{mg} /$ $\mathrm{m}^{2}$, suggesting a monolayer adsorption (Fukuzaki et al., 1996; Urano and Fukuzaki, 2000). Before alkali cleaning, a 2-g aliquot of the BSA-fouled $\mathrm{Al}_{2} \mathrm{O}_{3}$ particles was treated with $0.3 \%(\mathrm{~V} / \mathrm{v})$ gaseous ozone at room temperature and approximately $0 \%$ relative humidity $(\mathrm{RH})$ for 8 to $120 \mathrm{~min}$ as described previously (Takehara et al., 2000).

Batchwise cleaning was conducted by introducing a 1-g portion of BSA-fouled $\mathrm{Al}_{2} \mathrm{O}_{3}$ particles and $5 \mathrm{ml}$ of $\mathrm{NaOH}$ solution ( $\mathrm{pH} 9.2$ to 13.7 ) or $5 \mathrm{ml}$ of alkaline electrolyzed water ( $\mathrm{pH} 10.5$ to 11.7 ) into $25-\mathrm{ml}$ glass vial, which was then laid on its side in a water bath at $40^{\circ} \mathrm{C}$ and reciprocally shaken (140 oscillations per min) for $2 \mathrm{~h}$. After being shaken, the vial was centrifuged at $2300 \times g$ for $10 \mathrm{~min}$. The BSA concentration in the supernatant obtained, i.e., the amount of BSA removed $(R)$, and the amount of BSA still remaining on the $\mathrm{Al}_{2} \mathrm{O}_{3}\left(S_{r}\right)$ were measured by the Lowry-Folin method as described previously (Lowry et al., 1951 Urano and Fukuzaki, 1997; ). The efficiency of BSA

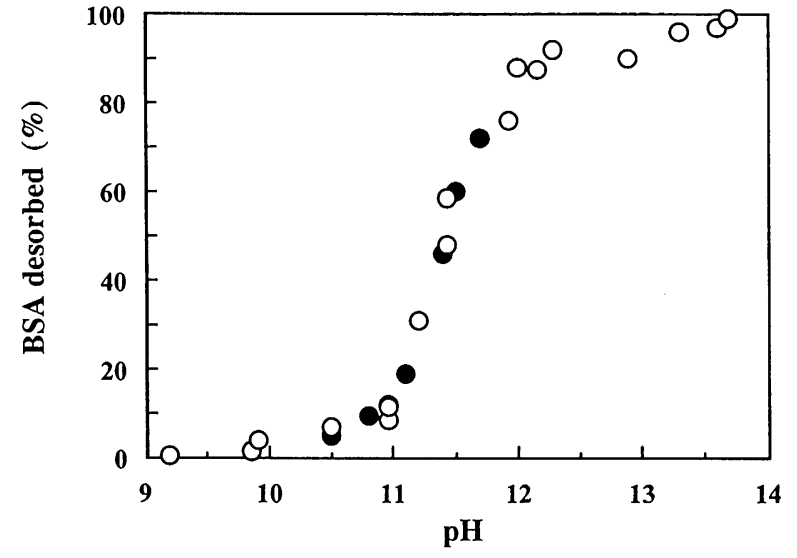

FIG. 1. Effect of $\mathrm{pH}$ on the desorption of $\mathrm{BSA}$ from $\mathrm{Al}_{2} \mathrm{O}_{3}$ when cleaned with a $\mathrm{NaOH}$ solution and alkaline electrolyzed water. Batchwise cleaning was conducted in a 25-ml glass vial for $120 \mathrm{~min}$ at $40^{\circ} \mathrm{C}$ with shaking (140 oscillations per min). Symbols: $\bigcirc$, cleaning with a $\mathrm{NaOH}$ solution; cleaning with alkaline electrolyzed water.

desorption was expressed as the percentage of $R$ to $\Gamma\{(R / \Gamma) \times 100\}$.

Continuous cleaning was conducted by introducing a 1-g portion of ozone-treated and non-ozone-treated BSA-fouled $\mathrm{Al}_{2} \mathrm{O}_{3}$ particles into a stainless steel column $(4 \mathrm{~mm} \phi \times 50 \mathrm{~mm})$ held vertically in a column oven at $40^{\circ} \mathrm{C}$ and then by feeding alkaline electrolyzed

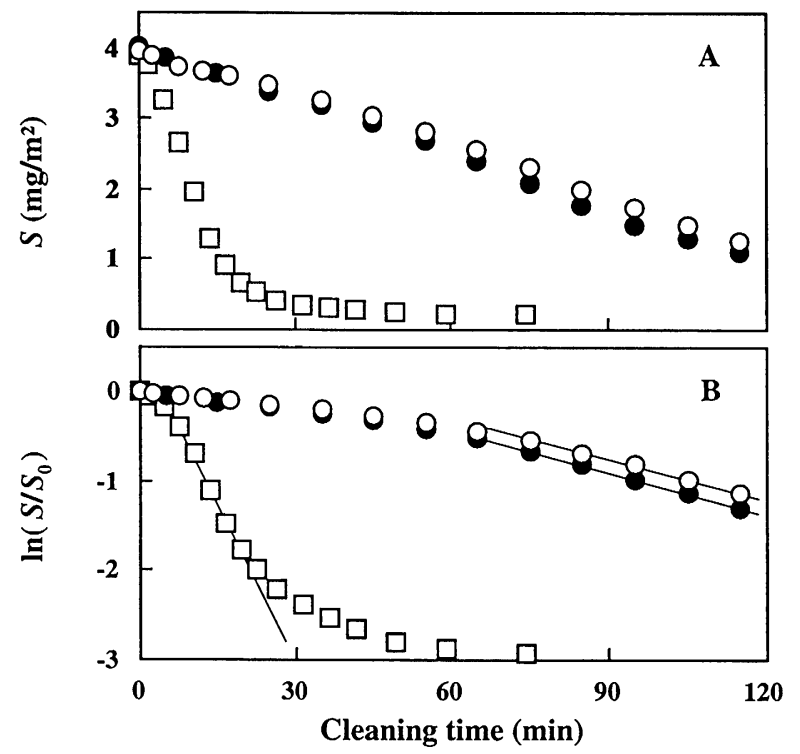

FIG. 2. Time courses of $B S A$ desorption from $\mathrm{Al}_{2} \mathrm{O}_{3}$ surfaces during continuous cleaning with $\mathrm{NaOH}$ solutions and alkaline electrolyzed water. (A) $S$ versus $t$, (B) $\ln \left(S / S_{0}\right)$ versus $t$. Continuous cleaning was conducted in a stainless steel column at $40^{\circ} \mathrm{C}$ for 120 min by continuously feeding the $\mathrm{NaOH}$ solution or alkaline electrolyzed water from the bottom of the column at a space time of $1.25 \mathrm{~min}$. Symbols: $\bigcirc, \mathrm{NaOH}$ solution of $\mathrm{pH} 11.8 ; \square, \mathrm{NaOH}$ solution of $\mathrm{pH} 12.8$; , alkaline electrolyzed water of $\mathrm{pH} 11.7$. 
water $(\mathrm{pH}$ 11.7) or $\mathrm{NaOH}$ solution $(\mathrm{pH} 11.8$ and 12.8) from the bottom of the column at a flow rate of $0.3 \mathrm{ml} / \mathrm{min}$ (space time $=1.25 \mathrm{~min}$ ) (Takehara et al., 2000). The alkali eluent was fractionally collected, and its BSA concentration was measured by the Lowry-Folin method. The difference between the measured concentrations of ozone-treated and nonozone-treated BSA due to the oxidation of Lowrypositive sites, i.e., tryptophan, tyrosine, and peptide bonds, was amended by comparing the standard curves for non-ozone-treated and ozone-treated BSA. After continuous cleaning, the particles were withdrawn from the column and $S_{r}$ was determined by the Lowry-Folin method as described above.

Figure 1 shows the effect of $\mathrm{pH}$ of the $\mathrm{NaOH}$ solution and alkaline electrolyzed water on the efficiency of $\mathrm{BSA}$ desorption from the $\mathrm{Al}_{2} \mathrm{O}_{3}$ surfaces during batch cleaning. In the case of cleaning with $\mathrm{NaOH}$ solution, the efficiency of BSA desorption was considerably low at $\mathrm{pHs}$ lower than 11, but above which it increased gradually with increasing $\mathrm{pH}$ and reached about $98 \%$ at pH 13.7. The removal of BSA by cleaning with alkaline electrolyzed water also depended on $\mathrm{pH}$. The relationship between the efficiency of BSA desorption and $\mathrm{pH}$ obtained for cleaning with alkaline electrolyzed water over the $\mathrm{pH}$ range of 10.5 to 11.7 almost coincided with that obtained for cleaning with the $\mathrm{NaOH}$ solution. These results indicated that the ability of alkaline electrolyzed water to remove BSA from $\mathrm{Al}_{2} \mathrm{O}_{3}$ depended on $\mathrm{pH}$, i.e., hydroxide ion concentration.

Figure $2 \mathrm{~A}$ shows time course changes in the amount of residual $\mathrm{BSA}(S)$ on $\mathrm{Al}_{2} \mathrm{O}_{3}$ surfaces during continuous cleaning with $\mathrm{NaOH}$ solutions of $\mathrm{pH} 11.8$ and 12.8 , and with alkaline electrolyzed water of $\mathrm{pH}$ 11.7. During 75 min of cleaning with the $\mathrm{NaOH}$ solution of $\mathrm{pH} 12.8$, BSA was readily desorbed with a short lag time and approximately $95 \%$ fraction of adsorbed BSA was removed $\left(S_{r}=0.21 \mathrm{mg} / \mathrm{m}^{2}\right)$. On the other hand, BSA desorption occurred very slowly and similar desorption rates were observed when using the $\mathrm{NaOH}$ solution of $\mathrm{pH} 11.8$ and alkaline electrolyzed water. Figure $2 \mathrm{~B}$ shows semilogarithmic graphs of the data in Fig. $2 \mathrm{~A}$, in which the ordinate is the natural logarithm of the ratio of $S$ at any time $t$ to the amount of BSA at time $0\left(S_{0}=\Gamma\right)$. Assuming that the rate of BSA desorption is directly proportional to $S$, as proposed by Jennings (1965), the following first-order equation will become valid:

$$
-\mathrm{d} S / \mathrm{d} t=k S
$$

where $k$ is the first-order desorption rate constant. On integration and rearrangement, eq. 1 gives the following:

$$
\ln \left(S / S_{0}\right)=-k t
$$

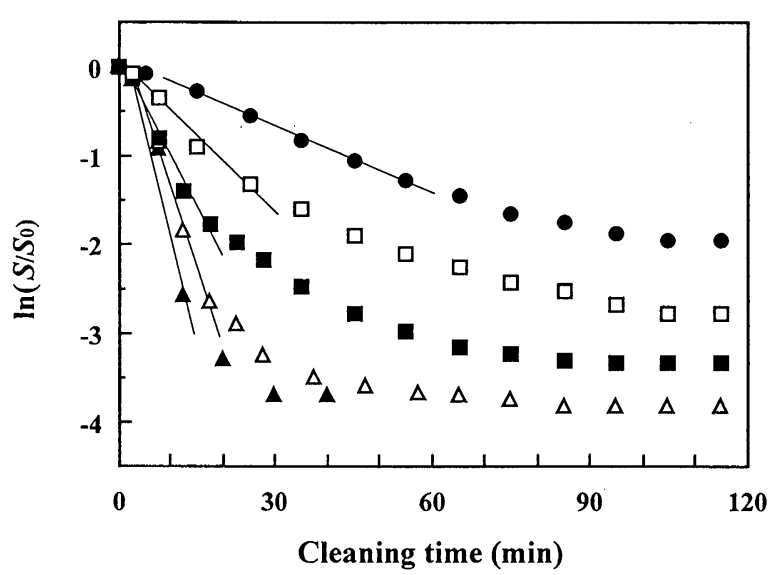

FIG. 3. Time courses of BSA desorption from $\mathrm{Al}_{2} \mathrm{O}_{3}$ surfaces during continuous cleaning with alkaline electrolyzed water combined with ozone pretreatment. Before cleaning, BSA-fouled $\mathrm{Al}_{2} \mathrm{O}_{3}$ particles were pretreated with $0.3 \%$ (v/ v) gaseous ozone for $8(\mathbf{O}), 15(\square), 30(\square), 60(\triangle)$, or $120 \mathrm{~min}(\mathbf{\Delta})$ at room temperature and ca. $0 \% \mathrm{RH}$. Cleaning conditions are given in the legend to Fig. 2.

so that the graph of $\ln \left(S / S_{0}\right)$ versus $t$ is expressed as a straight line. However, for instance, the whole curve of BSA desorption during cleaning with the $\mathrm{NaOH}$ solution of $\mathrm{pH} 12.8$ was not described by simple first-order kinetics. This suggests that there exists different types of conformations of $\mathrm{BSA}$ on $\mathrm{Al}_{2} \mathrm{O}_{3}$ surfaces. Nevertheless, the linear portion of BSA desorption occurs in the initial stage of cleaning, indi-

TABLE 1. The $k$ and $S$, values obtained for cleaning with alkaline electrolyzed water ( $\mathrm{pH} 11.7)$ with and without ozone

\begin{tabular}{|c|c|c|c|}
\hline Caustic solution & $\begin{array}{c}\text { Ozone }(0.3 \%, \mathrm{v} / \mathrm{v}) \\
\text { pretreatment time } \\
(\mathrm{min})\end{array}$ & $\begin{array}{c}k \\
\left(\min ^{-1}\right) \\
\end{array}$ & $\begin{array}{c}S_{r} \\
\left(\mathrm{mg} / \mathrm{m}^{2}\right)\end{array}$ \\
\hline \multirow{5}{*}{$\begin{array}{l}\text { Alkaline electro- } \\
\text { lyzed water (pH11.7) }\end{array}$} & - & 0.014 & 1.27 \\
\hline & 8 & 0.025 & 0.54 \\
\hline & 15 & 0.060 & 0.25 \\
\hline & 30 & 0.128 & 0.14 \\
\hline & 60 & 0.166 & 0.09 \\
\hline \multirow[t]{6}{*}{$\begin{array}{l}\mathrm{NaOH} \text { solution } \\
\mathrm{pH} 11.8\end{array}$} & 120 & 0.242 & 0.09 \\
\hline & - & 0.015 & 1.11 \\
\hline & - & 0.102 & 0.21 \\
\hline & - & 0.138 & 0.13 \\
\hline & - & 0.240 & 0.12 \\
\hline & - & 0.240 & 0.10 \\
\hline
\end{tabular}
pretreatment, and for that with $\mathrm{NaOH}$ solutions of different $\mathrm{pHs}$.

BSA-fouled $\mathrm{Al}_{2} \mathrm{O}_{3}$ particles were pretreated with $0.3 \%(\mathrm{~V} /$ v) gaseous ozone at room temperature for 8 to $120 \mathrm{~min}$. For cleaning conditions, see the legend to Fig. 2.

${ }^{a}$ Reported by Takehara et al. (2000). 
cating that BSA desorption in this phase apparently follows first-order kinetics. Similarly, the desorption curves during the cleaning with the $\mathrm{NaOH}$ solution of $\mathrm{pH} 11.8$ and alkaline electrolyzed water also had linear portions in parts. The slope of the linear portion is considered to be a measure sufficient to assess the cleaning rate (Jennings, 1965; Nagata et al. 1995; Sarkar and Chattoraj, 1996). Therefore, we evaluated the $k$ from the slope of the linear portion of each desorption curve as a measure of the cleaning rate. The $k$ values obtained for cleaning with the $\mathrm{NaOH}$ solution of $\mathrm{pH} 11.8$ and 12.8, and alkaline electrolyzed water $(\mathrm{pH} 11.7)$ were $0.014,0.102$, and $0.015 \mathrm{~min}^{-1}$, respectively (see Table 1). Apparently, the rate of BSA desorption during cleaning with alkaline electrolyzed water also depended on $\mathrm{pH}$.

The effect of pretreatment with $0.3 \%$ gaseous ozone for 8 to 120 min on the efficiency of cleaning with alkaline electrolyzed water was examined. Figure 3 shows the curves of BSA desorption from $\mathrm{Al}_{2} \mathrm{O}_{3}$ surfaces during continuous cleaning with alkaline electrolyzed water $(\mathrm{pH}$ 11.7) combined with ozone pretreatment. Pretreatment of BSA-fouled $\mathrm{Al}_{2} \mathrm{O}_{3}$ with ozone was found to markedly facilitate the desorption of BSA. The effect of ozone pretreatment on the rate of BSA desorption clearly depended on the length of pretreatment. In addition, $S_{r}$ value decreased depending on the length of pretreatment. The effect of ozone pretreatment on facilitation of BSA desorption can probably be attributed to the partial decomposition of the adsorbed BSA molecules by ozone, which in turn could accelerate the swelling and dispersion of peptized fragments in alkaline electrolyzed water (Takehara et al., 2000).

For all the desorption curves in Fig. 3 , the $k$ values were also evaluated from the slopes of the linear portions of the desorption curves in the initial stage of cleaning. The $k$ and $S$, values obtained for cleaning with gaseous ozone and alkaline electrolyzed water in combination are summarized in Table 1. By conducting ozone pretreatment for $120 \mathrm{~min}$, a higher $k$ value of $0.24 \mathrm{~min}^{-1}$ was achieved even with alkaline electrolyzed water of $\mathrm{pH}$ 11.7. The $S_{\mathrm{r}}$ value also decreased from 1.27 (non-ozone-treatment) to 0.09 $\mathrm{mg} / \mathrm{m}^{2}$ by lengthening the pretreatment to 60 and 120 min. We reported that the $k$ and $S$, values obtained for cleaning with $\mathrm{NaOH}$ solution of $\mathrm{pH} 13.1$ to 13.7 alone under the same conditions as this study were between 0.14 and $0.24 \mathrm{~min}^{-1}$ and between 0.13 and $0.10 \mathrm{mg} / \mathrm{m}^{2}$, respectively (Takehara et al., 2000) (see Table 1). These values were in good agreement with the $k$ and $S$, values obtained for cleaning with alkaline electrolyzed water combined with ozone pretreatment for 30 to $120 \mathrm{~min}$. Thus, ozone pretreatment greatly improved the efficiency of cleaning of BSAfouled $\mathrm{Al}_{2} \mathrm{O}_{3}$ with alkaline electrolyzed water.

In a laboratory model system, it was suggested that the efficiency of cleaning of $\mathrm{BSA}$-fouled $\mathrm{Al}_{2} \mathrm{O}_{3}$ with the combined use of gaseous ozone and alkaline electrolyzed water is comparable to that of cleaning with high-pH $\mathrm{NaOH}$ solutions $(\mathrm{pH}>13.0)$ alone. Although application of ozone pretreatment is limited by ozone-resistant equipment material, alkaline electrolyzed water appears to be available for the cleaning of protein-fouled surfaces when used in combination with gaseous ozone.

\section{REFERENCES}

Clegg, L. F. L. (1962) Cleaning and sterilization of milking equipment on the farm. In Milk Hygiene (F.A.O./W.H.O.), pp.195-220, World Health Organization, Geneva.

Fukuzaki, S., Urano, H., and Nagata, K. (1996) Adsorption of bovine serum albumin onto metal oxide surfaces. J. Ferment. Bioeng., 81, 163-167.

Jennings, W. G. (1965) Theory and practice of hard-surface cleaning. In Advances in Food Research, Vol. 14 (Chichester, C. O. and Mark, E. M., ed.), pp.325-458, Academic Press, New York.

Lowry, O. H., Rosenbrough, N. J., Farr, A. L., and Randall, R. J. (1951) Protein measurement with the Folin phenol reagent. J. Biol. Chem., 193, 265-275.

Mitchell, T. (1981) Cleaning of CIP systems. Dairy Food Sanit., 1, 292-293.

Nagata, A., Sakiyama, T., Itoh, H., Toyomasu, T., Enomoto, E., Nagai, T., Saeki, T., and Nakanishi, K. (1995) Comparative study on caustic and enzymatic cleanings of stainless steel surface fouled with $\beta$-lactoglobulin. Biosci. Biotechnol. Biochem., 59, 2277-2281.

Nakagawara, S., Goto, T., Nara, M., Ozawa, Y., Hotta, K., and Arata, Y. (1998) Spectroscopic characterization and the $\mathrm{pH}$ dependence of bactericidal activity of the aqueous chlorine solution. Anal. Sci., 14, 691-698.

Sarkar, D., and Chattoraj, D. K. (1996) Kinetics of desorption of proteins from the surface of protein-coated alumina by various desorbing reagent. J. Colloid Interface Sci., 178, 606-613.

Takehara, A., Urano, H., and Fukuzaki, S. (2000) Effect of ozone pretreatment on alkali cleaning of alumina fouled with bovine serum albumin. J. Biosci. Bioeng., 89, 267270.

Twomey, A. (1968) The physics and chemistry of cleaning. New Zealand J. Dairy Technol., 3, 150-159.

Ueda, S., and Kuwabara Y. (1999) Disinfection of fresh vegetables by various means and the bactericidal effects of strong acidic electrolyzed solutions on enteropathogenic bacteria (in Japanese), Bokin Bobai, 27, 301-307.

Urano, H., and Fukuzaki, S. (1997) Influence of anionic compounds on adsorption behavior of bovine serum albumin at oxide-water interfaces. J. Ferment. Bioeng., 83, 261-266.

Urano, H., and Fukuzaki, S. (2000) Conformation of adsorbed Bovine serum albumin governing its desorption behavior at alumina-water interfaces. J. Biosci. Bioeng., 90, 105-111. 